\title{
Pengaruh Penambahan Kulit Singkong dan Bakteri Asam Laktat sebagai Aditif Pakan terhadap Profil Saluran Pencernaan Ayam Pedaging
}

\section{Effect of Addition of Cassava Peel and Lactic Acid Bacteria as Feed Additives on The Digestive Profile Of Broiler Chicken}

\author{
Purwinarto*, E. Suprijatna, dan S. Kismiati \\ Laboratorium Produksi Ternak Unggas, Fakultas Peternakan dan Pertanian Universitas Diponegoro \\ Jl. Prof. H. Soedarto, S.H - Tembalang Semarang, 50275 - Indonesia \\ *Corresponding E-mail: purwinarto12@gmail.com
}

(Diterima: 4 November 2019; Disetujui: 2 Januari 2020)

\begin{abstract}
ABSTRAK
Penelitian bertujuan untuk mengkaji bobot organ saluran pencernaan ayam pedaging yang diberi pakan menggunakan aditif pakan kombinasi kulit singkong dan bakteri asam laktat dalam bentuk cair. Materi yang digunakan yaitu 144 ekor ayam pedaging umur 10 hari dengan rata-rata bobot badan awal pemeliharaan 198,59 gram $\pm 8,12$ yang di distribusikan pada 24 unit percobaan dalam rancangan acak lengkap (RAL) dengan 4 perlakuan dan 6 ulangan. Perlakuan yang diterapkan adalah T0 : ransum basal; $\mathrm{T} 1$ : ransum basal $+50 \mathrm{ml}$ aditif pakan $/ \mathrm{kg}$ ransum; $\mathrm{T} 2:$ ransum basal $+100 \mathrm{ml}$ aditif pakan $/ \mathrm{kg}$ ransum dan $\mathrm{T} 3$ : ransum basal $+150 \mathrm{ml}$ aditif pakan/kg ransum. Data yang diperoleh selanjutnya diolah secara statistik dengan Analisys of Variance (Anova) dengan taraf signifikansi 5\%. Hasil penelitian menunjukkan bahwa perlakuan dengan penambahan aditif pakan di dalam ransum tidak berpengaruh nyata $(\mathrm{P}>0,05)$ terhadap bobot relatif proventrikulus, ventrikulus, usus halus dan seka. Kesimpulan dari penelitian adalah aditif pakan kombinasi kulit singkong dan bakteri asam laktat belum mampu meningkatkan bobot relatif organ pencernaan ayam pedaging.
\end{abstract}

Kata kunci: aditif pakan, bakteri asam laktat, kulit singkong, saluran pencernaan

\section{ABSTRACT}

The aim of this study was to examine the organ weights of the digestive tract of broiler chickens fed using a food additive using a combination of cassava peel and lactic acid bacteria in liquid form. The material used was 144 broilers aged 1 day with an average initial body weight of $40.55 \pm 11.52$ grams distributed to 24 experimental units in a completely randomized design (CRD) with 4 treatments and 6 replications. The treatments applied were T0 : basal ration; $T 1$ : basal ration $+50 \mathrm{ml}$ feed additives $/ \mathrm{kg}$ ration; $T 2$ : basal ration $+100 \mathrm{ml}$ feed additives / $\mathrm{kg}$ ration; $T 3$ : basal ration $+150 \mathrm{ml}$ feed additives / $\mathrm{kg}$ ration. The data obtained were processed statistically with Analysis of Variance (ANOVA) with a significance level of 5\%. The results showed that the treatment with the addition of feed additives in the ration had no significant effect $(P>0.05)$ on the relative weight of the proventriculus, ventriculus, small intestine, and Seka. The conclusion of the study is the feed additives of cassava peel combination and lactic acid bacteria has not been able to increase the relative weight of the digestive organs of broiler chickens.

Keywords: cassava peel, digestive tract, feed additives, lactic acid bacteria

\section{PENDAHULUAN}

Ayam pedaging merupakan salah satu sumber protein hewani yang utama bagi masyarakat Indonesia, karena harga yang lebih terjangkau masyarakat dibanding dengan daging ternak yang lain. Populasi ayam pedaging semakin meningkat karena tingginya tingkat konsumsi daging unggas oleh masyarakat, sesuai data Badan Pusat Statistik (BPS) pada tahun 2009 - 2018 populasi ayam pedaging di Indonesia meningkat setiap 
tahunnya, pada tahun 2018 populasi ayam broiler sebanyak 1.891.434.612 ekor (BPS, 2018). Ayam pedaging memiliki performans yang sangat baik dengan karakteristik khusus yaitu pertumbuhan cepat, memiliki daging yang tebal serta relatif cepat dalam pemeliharaan dengan rentang waktu 28 35 hari (Tamalludin, 2012). Kendala dalam pemeliharaan ayam pedaging yaitu harga pakan yang tinggi dan potensi terkena penyakit tinggi (Ulupi et al., 2015). Perkembangan ayam pedaging yang terus meningkat membuat perusahaan pakan, obat maupun vaksin berusaha mencari solusi terbaik untuk mengatasi kendala tersebut. Penggunaan obat-obatan seperti antibiotik menjadi salah satu upaya, karena antibiotik selain digunakan sebagai pengobatan penyakit juga digunakan sebagai pemacu dalam pertumbuhan ternak. Namun penggunaan antibiotik dalam pakan sudah dilarang tercantum pada pasal 16 Permentan No. 14 tahun 2017 tentang Klasifikasi Obat Hewan, karena pengunaan antibiotik secara terus menerus dapat meninggalkan residu pada produk ternak sehingga berbahaya apabila dikonsumsi oleh konsumen (Sumarsih et al., 2012).

Limbah agroindustri pertanian di Indonesia sangat melimpah dan meningkat setiap tahun, salah satunya yaitu kulit singkong. Data Badan Pusat Statistik (BPS) memperlihatkan bahwa pada tahun 2000 produksi singkong mencapai 16,10 juta ton dan produksi singkong meningkat menjadi 21,80 juta ton pada tahun 2015 (BPS, 2015). Singkong mampu menghasilkan 15 hingga $20 \%$ kulit singkong setiap satu kilogramnya (Hidayat, 2009). Kulit singkong memiliki kandungan oligosakarida berupa inulin $0,12 \%$, maltopentosa $0,003 \%$, rafinosa $0,06 \%$, mannosa $1,99 \%$, sukrosa $1,39 \%$ dan arabinosa $0,01 \%$, dimana oligosakarida yang terkandung dalam kulit singkong dapat difermentasi oleh bakteri asam laktat (BAL) dalam saluran pencernaan ayam pedaging (Selviana et al., 2019). Penggunaan kombinasi antara kulit singkong sebagai prebiotik dan bakteri asam laktat sebagai probiotik yang dapat dijadikan aditif pakan dalam ransum ayam pedaging.

Penggunaan probiotik dan prebiotik dalam pakan mampu meningkatkan kekebalan tubuh, menurunkan $\mathrm{pH}$ usus dan membantu meningkatkan kinerja saluran pencernaan dengan merangsang sekresi enzim pankreas denganmenekan pertumbuhan bakteripatogen, meningkatkan pertumbuhan mikroflora yang bermanfaat dan memastikan enzim pencernaan berfungsi secara optimal (Bozkurt et al., 2009). Selain itu, probiotik mampu meningkatkan tinggi vili sehingga penyerapan nutrisi dalam usus halus menjadi lebih efisien dan meningkat (Park and Kim, 2014). Kadar keasaman yang meningkat mengakibatkan bakteri patogen terlambat perkembangannya, serta aktivitas enzim-enzim pencernaan meningkat sehingga kecernaan pakan juga meningkat (Chaiyasut et al., 2017). Aktivitas pencernaan yang meningkat akan mengakibatkan perubahan morfologi saluran pencernaan yang berkembang lebih optimal (Hamid et al., 2014). Dengan demikian penggunaan aditif pakan kombinasi antara kulit singkong sebagai prebiotik dan bakteri asam laktat sebagai probiotik diharapkan mampu meningkatkan perkembangan saluran pencernaan ayam pedaging.

Penelitian ini bertujuan untuk mengkaji pemanfaatan kulit singkong yang dikombinasikan dengan Bakteri Asam Laktat (BAL) sebagai aditif pakan dalam ransum ayam pedaging terhadap bobot relatif saluran pencernaan. Manfaat penelitian adalah dapat memperoleh informasi level pemberian aditif pakan yang optimal terhadap bobot relatif saluran pencernaan ayam pedaging.

\section{METODE}

Penelitian dilaksanakan pada Oktober 2018 - Januari 2019 di Laboratorium Produksi Ternak Unggas, Fakuktas Peternakan dan Pertanian Universitas Diponegoro, Semarang.

\section{Materi}

Materi yang digunakan dalam penelitian ini meliputi 144 ekor ayam 
Tabel 1. Komposisi dan kandungan nutrisi ransum perlakuan ayam pedaging

\begin{tabular}{lcc}
\hline Komposisi Bahan Pakan & Starter & Finisher \\
\hline Jagung (\%) & 45,55 & 50,00 \\
Bekatul (\%) & 15,65 & 20,00 \\
Tepung Ikan (\%) & 7,00 & 7,00 \\
Bungkil Kedelai (\%) & 25,80 & 17,00 \\
MBM (\%) & 3,00 & 3,00 \\
Premix (\%) & 1,00 & 1,00 \\
CaCO $\left._{3} \%\right)$ & 2,00 & 2,00 \\
\hline Total & 100 & 100 \\
\hline Kandungan Nutrisi dalam ransum: & & \\
Energi Metabolis (Kkal)** & $3.029,19$ & $3.048,86$ \\
Protein Kasar (\%)* & 22,27 & 18,99 \\
Lemak Kasar (\%)* & 6,69 & 7,37 \\
Serat Kasar (\%)* & 7,11 & 7,60 \\
Kalsium (\%)* & 1,51 & 1,47 \\
Phospor (\%)* & 0,72 & 0,75 \\
\hline Ketrang: *Ber
\end{tabular}

Keterangan: *Berdasarkan kering udara

**Berdasarkan perhitungan dengan rumus Balton (Siswohardjono, 1982) EM (Kkal/kg) = $40,81[0,87(\mathrm{PK}+2,25 \times \mathrm{LK}+\mathrm{BETN}+\mathrm{k})]$

pedaging umur 10 hari dengan rata-rata bobot badan awal pemeliharaan 198,59 gram $\pm 8,12$. Perlengkapan dan peralatan yang digunakan selama penelitian adalah 24 petak kandang dengan ukuran $75 \mathrm{~cm} \times 75 \mathrm{~cm}$ dengan alas sekam yang diisi 6 ekor ayam pedaging. Timbangan digital digunakan untuk menimbang komposisi ransum dan bobot ayam setiap minggu. Komposisi dan kandungan nutrisi ransum perlakuan dapat dilihat pada Tabel 1. Bahan komposisi ransum kemudian dianalisis proksimat di Laboratorium Imu Nutrisi Pakan Fakultas Peternakan dan Pertanian Universitas Diponegoro, Semarang dan disusun menjadi ransum basal.

\section{Metode}

\section{Pembuatan Tepung Kulit Singkong}

Pembuatan tepung kulit singkong dilakukan dengan penyiapan kulit ari singkong terlebih dahulu yang berasal dari Industri Singkong Keju D9 salatiga. Kulit ari singkong kemudian di cuci lalu dijemur dibawah sinar matahari selama 3 hari dan digiling menjadi tepung setelah itu di sterilisasi dengan alat steamer.

\section{Pembuatan Aditif Pakan}

Pembuatan probiotik dilakukan dengan isolasi bakteri asam laktat dari usus itik pada bagian sekum sepanjang $\pm 10 \mathrm{~cm}$, kemudian dilakukan proses inkubasi dan kulturisasi sehingga di dapat hasil akhir indukan bakteri asam laktat sebesar 2,3 $\times 10^{8} \mathrm{CFU} / \mathrm{ml}$. Tahap selanjutnya penentuan kandungan prebiotik dengan mencampur kulit singkong sebanyak $4 \%$ ( 0,4 gram), $5 \%$ (0,5 gram) dan $6 \%(0,6$ gram) setelah itu masing-masing dicampur dengan probiotik yang terdiri dari $10 \mathrm{ml}$ aquades ditambah $1 \mathrm{ml}$ kultur bakteri asam laktat kemudian diinkubasi selama 24 jam pada suhu $37^{\circ} \mathrm{C}$. Dilakukan pengenceran dan diperoleh hasil tertinggi sebesar $6,5 \times 10^{9} \mathrm{CFU} /$ $\mathrm{ml}$, kemudian prebiotik yang menghasilkan CFU tertinggi dipilih sebagai prebiotik yaitu sebesar (6\%) 0,6 gram. Penggabungan aditif pakan dilakukan dengan mencampur $10 \mathrm{ml}$ probiotik yang ditambah $100 \mathrm{ml}$ aquades dan 
6\% kulit singkong lalu diinkubasi selama 24 jam. Tehap selanjutnya yaitu uji ketahanan bakteri dalam ransum dengan cara aditif pakan di spray pada ransum kemudian dilakukan pengamatan bakteri setiap 4 jam dan 12 jam sekali selama 24 jam.

\section{Tahap Penerapan Perlakuan Kedalam Ransum}

Pemeliharaan dimulai pada umur 1 hari sampai dengan umur 38 hari. Pemeliharaan pada umur 1 - 10 hari digunakan pakan starter komersial br11. Tahap perlakuan dilakukan pada umur 11 - 38 hari, pakan yang digunakan pada tahap perlakuan yaitu T0 : pemberian ransum basal tanpa aditif pakan (kontrol), $\mathrm{T} 1$ : pemberian ransum basal $+50 \mathrm{ml}$ aditif pakan $/ \mathrm{kg}, \mathrm{T} 2:$ pemberian ransum basal +100 $\mathrm{ml}$ aditif pakan $/ \mathrm{kg}$ dan $\mathrm{T} 3:$ pemberian ransum basal $+150 \mathrm{ml}$ aditif pakan $/ \mathrm{kg}$. Penambahan aditif pakan dilakukan dengan cara dituang dari botol dan dicampurkan secara merata ke dalam ransum basal kemudian diberikan di pagi hari. Penimbangan pakan dan sisa pemberian pakan dilakukan setiap hari, sedangkan penimbangan bobot badan dilakukan satu minggu sekali. Pelaksanaan vaksin dilakukan pada umur 3 hari untuk pemberian vaksin ND-AI dengan metode tetes mata dan umur 15 hari untuk pemberian vaksin ND-IB nelalui air minum.

Rancangan penelitian yang digunakan adalah Rancangan Acak Lengkap (RAL) dengan 4 perlakuan dan 6 ulangan. Perlakuan yang digunakan yaitu:

T0 : Pemberian ransum basal tanpa aditif pakan

T1 : Pemberian ransum basal $+50 \mathrm{ml}$ aditif pakan/ kg

T2 : Pemberian ransum basal $+100 \mathrm{ml}$ aditif pakan/ kg

T3 : Pemberian ransum basal $+150 \mathrm{ml}$ aditif pakan/ kg

Parameter yang diambil yaitu bobot saluran organ pencernaan ayam pedaging yang meliputi proventrikulus, ventrikulus, usus halus, dan seka.

\section{Tahap Pengambilan Data}

Pengambilan sampel bobot organ saluran pencernaan ayam pedaging dilakukan pada umur 38 hari. Satu ekor ayam pedaging diambil secara acak dari masing-masing unit percobaan kandang percobaan sehingga terdapat 24 ekor ayam sebagai sampel. Ayam pedaging ditimbang untuk mengetahui bobot hidupnya kemudian dilakukan proses penyembelihan dan pencabutan bulu, lalu dibuka bagian andomen dan diambil organ pencernaannya mulai dari proventikulus, ventrikulus, usus halus dan seka. Organ pencernaan dipisahkan sesuai bagian masingmasing, kemudian organ yang telah dipisahkan setiap bagiannya dibersihkan dari digesta dan ditimbang dengan timbangan digital untuk mengetahui bobot saluran pencernaan.

Data hasil penelitian ditampilkan dalam bobot relatif yang dihitung dengan rurmus berikut:

Bobot relatif $=\frac{\text { Bobot organ }}{\text { Bobot hidup }} \times 100 \%$

Sebagai data pendukung juga diamati kecernaan protein dan kecernaan serat kasar, dihitung dengan rumus Sibbald dan Wolynetz (1984) yaitu:

Kecernaan protein $(\%)=$ konsumsi protein - protein eksreta konsumsi protein

Kecernaan serat kasar $(\%)=$

konsumsi serat kasar - serat kasar eksreta konsumsi serat kasar

Data yang diperoleh selanjutnya diolah secara statistik dengan Analisis Varians (Anova).

\section{HASIL DAN PEMBAHASAN}

Bobot relatif saluran pencernaan ayam pedaging meliputi proventrikulus, ventrikulus, usus halus dan seka yang mendapat perlakuan penambahan aditif pakan berupa kombinasi 
JPI Vol. 22 (1): 101-109

Tabel 2. Hasil penelitian bobot organ pencernaan ayam pedaging umur 38 hari

\begin{tabular}{lcccc}
\hline \multirow{2}{*}{ Variabel } & \multicolumn{4}{c}{ Perlakuan } \\
\cline { 2 - 5 } & T0 & T1 & T2 & T3 \\
\hline Kecernaan SK (\%)* & $23,34 \pm 18,61$ & $38,73 \pm 14,56$ & $42,87 \pm 13,26$ & $40,52 \pm 5,28$ \\
Kecernaan Protein (\%)* & $84,39 \pm 5,07$ & $86,88 \pm 3,62$ & $86,31 \pm 3,21$ & $85,68 \pm 3,34$ \\
Proventrikulus (\%) & $0,63 \pm 0,11$ & $0,67 \pm 0,06$ & $0,71 \pm 0,04$ & $0,73 \pm 0,14$ \\
Ventrikulus (\%) & $1,94 \pm 0,19$ & $1,86 \pm 0,42$ & $1,84 \pm 0,16$ & $1,87 \pm 0,22$ \\
Usus halus (\%) & $4,22 \pm 0,40$ & $4,19 \pm 0,53$ & $3,97 \pm 0,26$ & $4,47 \pm 0,53$ \\
Seka (\%) & $0,42 \pm 0,06$ & $0,49 \pm 0,09$ & $0,45 \pm 0,03$ & $0,51 \pm 0,07$ \\
\hline
\end{tabular}

Keterangan: *Berdasarkan data hasil penelitian kelompok

antara bakteri asam laktat dan kulit singkong tidak berpengaruh nyata $(\mathrm{P}>0,05)($ Tabel 2).

\section{Pengaruh Perlakuan Terhadap Bobot Relatif Proventrikulus}

Penambahan kulit singkong dan bakteri asam laktat sebagai aditif pakan dalam ransum dengan dosis $50 \mathrm{ml} / \mathrm{kg}, 100 \mathrm{ml} / \mathrm{kg}$ dan $150 \mathrm{ml} / \mathrm{kg}$ tidak berpengaruh nyata terhadap bobot relatif proventrikulus ayam pedaging dengan hasil perhitungan berkisar antara 0,63 $-0,73 \%$ (Tabel 2). Hasil tersebut lebih tinggi dibanding penelitian Awad et al. (2009) bahwa penambahan kombinasi antara probiotik dan prebiotik berupa lactobacillus $s p$. dengan sawi putih sebanyak $0,1 \%$ dalam ransum tidak berpengaruh nyata yang menghasilkan bobot relatif proventrikulus pada kisaran $0,37-0,39 \%$. Penelitian lain oleh Sugiharto et al. (2018) bahwa dengan penambahan probiotik multistrain dengan kombinasi vitamin dan mineral dalam ransum sebanyak $1 \%$ menghasilkan bobot relatif proventrikulus tidak bebeda nyata dari kontrol berkisar antara $0,56-0,61 \%$.

Penambahan aditif pakan diharapkan mampu untuk merangsang aktivitas kerja organ proventrikulus ayam pedaging sehingga dapat berkembang dengan optimal. Peran dari Proventrikulus yaitu sebagai tempat terjadinya proses pencernaan protein pakan secara kimiawi atau enzimatis. Berdasarkan penelitian Handoko et al. (2013) bahwa dalam mencerna protein ransum, pepsinogen akan disekresi oleh organ proventrikulus.
Proventrikulus berfungsi mencerna protein yang dibantu oleh enzim pepsin, proses tersebut menghasilkan hydrochloric acid (HCI) yang disekresikan oleh grandular cell. Berdasarkan penelitian Sugiharto et al. (2018) bahwa apabila aktivitas pencernaan dalam organ proventrikulus meningkat akan mengakibatkan perubahan terhadap morfologi saluran tersebut sehingga mampu berkembang lebih optimal. Namun hasil penelitian menunjukkan penambahan aditif pakan dalam ransum dengan dosis $50 \mathrm{ml} / \mathrm{kg}, 100 \mathrm{ml} / \mathrm{kg}$ dan $150 \mathrm{ml} / \mathrm{kg}$ belum mampu meningkatkan bobot relatif proventrikulus sehingga hasilnya tidak berbeda dengan perlakuan tanpa aditif pakan. Probiotik yang terkandang dalam pakan tidak memberikan efek terhadap perkembangan bobot relatif proventrikulus karena efek dari probiotik lebih dominan di usus halus. Hal ini sesuai dengan penelitian Sugiharto et al. (2018) yang menyatakan bahwa pemberian probiotik tidak berpengaruh terhadap bobot relatif proventrikulus. Awad et al. (2009) menambahkan bahwa proventrikulus perkembangannya tidak dipengaruhi penambahan probiotik dalam pakan. Berdasarkan penelitian Iskandar (2004) bahwa faktor yang mempengaruhi perkembangan organ proventrikulus salah satunya yaitu aktivitas pencernaan protein ransum. Namun, Tabel 2. menunjukkan bahwa kecernaan protein yang terjadi dari kontrol (T0) hingga perlakuan (T3) relatif sama yaitu berada pada rentang $84,39-86,88 \%$. Sehingga bobot relatif proventrikulus dengan 
penambahan aditif pakan yang dihasilkan tidak berbeda dengan perlakuan tanpa aditif pakan karena aktivitas pencernaan ransum yang relatif sama.

\section{Pengaruh Perlakuan Terhadap Bobot Relatif Ventrikulus}

Penambahan kulit singkong dan bakteri asam laktat sebagai aditif pakan dalam ransum dengan dosis $50 \mathrm{ml} / \mathrm{kg}, 100 \mathrm{ml} / \mathrm{kg}$ dan $150 \mathrm{ml} /$ $\mathrm{kg}$ tidak berpengaruh nyata terhadap bobot relatif ventrikulus ayam pedaging dengan hasil perhitungan berkisar antara $1,57-2,85 \%$ (Tabel 2). Hasil tersebut masih dalam kisaran normal. Berdasarkan penelitian Hossain et al. (2015) dengan penambahan Bacillus subtilis, Clostridium butyricum and Lactobacillus acidophilus (Tri-strain probiotik) pada ransum sebanyak $0,2 \%$ tidak berpengaruh nyata yang menghasilkan bobot relatif ventrikulus pada kisaran 1,57 - 1,67\%. Penelitian lain oleh Park and Kim (2014) bahwa probiotik Bacillus Subtilis B2A yang digunakan dalam ransum $1.0 \times 10^{5} \mathrm{cfu} / \mathrm{kg}$ menghasilkan bobot relatif ventrikulus tidak berbeda nyata dari kontrol berkisar $1,0-1,02 \%$.

Penambahan aditif pakan diharapkan mampu untuk meningkatkan pencernaan secara mekanis sehingga organ ventrikulus ayam pedaging dapat berkembang dengan optimal. Ventrikulus berperan dalam mencerna ransum secara mekanik. Berdasarkan penelitian Mahmilia (2005) bahwa perkembangan organ ventrikulus dipengaruhi oleh aktivitas kerja ventrikulus dalam mencerna serat kasar pakan. Kecernaan serat kasar dari kontrol (T0) hingga perlakuan (T3) yaitu berada pada rentang 23,34 42,87\%. Mahmilia (2005) menyatakan bahwa otot dinding organ ventrikulus akan bekerja lebih keras apabila kadar serat kasar yang dicerna semakin tinggi sehingga mampu meningkatkan perkembangan organ ventrikulus. Selain itu, berdasarkan penelitian Anggoro et al. (2019) bahwa aktivitas kerja pencernaan organ ventrikulus yang meningkat akan mengakibatkan perubahan terhadap morfologi saluran tersebut sehingga dapat berkembang lebih optimal.
Namun hasil penelitian menunjukkan penambahan aditif pakan dalam ransum dengan dosis $50 \mathrm{ml} / \mathrm{kg}, 100 \mathrm{ml} / \mathrm{kg}$ dan 150 $\mathrm{ml} / \mathrm{kg}$ belum mampu meningkatkan bobot relatif ventrikulus sehingga hasilknya tidak berbeda dengan perlakuan tanpa aditif pakan. Hal ini sesuai dengan penelitian Hossain et al. (2015) yang menyatakan bahwa penambahan probiotik dalam rasum tidak berpengaruh terhadap bobot relatif ventrikulus ayam pedaging. Berdasarkan penelitian Hossain et al. (2015) bahwa penambahan Bacillus subtilis, Clostridium butyricum dan Lactobacillus acidophilus (Tri-strain probiotik) pada ransum sebanyak $0,2 \%$ tidak mampu memperbaiki kondisi organ ventrikulus karena strain probiotik yang digunakan kurang baik, persiapan yang kurang, dosis pemberian tidak tepat dan komposisi ransum tidak memenuhi kebutuhan nutrisi ternak.

\section{Pengaruh Perlakuan Terhadap Bobot Relatif Usus Halus}

Penambahan kulit singkong dan bakteri asam laktat sebagai aditif pakan dalam ransum dengan dosis $50 \mathrm{ml} / \mathrm{kg}, 100 \mathrm{ml} / \mathrm{kg}$ dan $150 \mathrm{ml} / \mathrm{kg}$ tidak berpengaruh nyata terhadap bobot relatif usus halus ayam pedaging dengan hasil perhitungan berkisar antara 3,97-4,47\% (Tabel 2). Hasil tersebut lebih tinggi dibanding penelitian Awad et al. (2009) bahwa dengan penambahan kombinasi antara probiotik dan prebiotik berupa lactobacillus $s p$. dengan sawi putih sebanyak $0,1 \%$ dalam ransum menghasilkan bobot relatif usus halus lebih tinggi dari kontrol berkisar antara 2,89 $3,17 \%$ namun tidak berbeda nyata. Penelitian lain oleh Anggoro et al. (2019) bahwa dengan penambahan kulit pisang fermentasi dengan chrysonilia crassa dan bacillus subtilis sebanyak $10 \%$ dalam ransum mengahasilkan bobot relatif usus halus yang tidak berbeda nyata dari kontrol yaitu pada kisaran 3,01 $3,34 \%$.

Penambahan aditif pakan diharapkan mampu untuk meningkatkan populasi bakteri saluran pencernaan dan aktivitas pencernaan, menstabilkan $\mathrm{pH}$ usus serta merangsang kerja 
enzim untuk menekan pertumbuhan bakteri patogen sehingga usus halus ayam pedaging dapat berkembang dengan optimal. Awad et al. (2009) menyatakan bahwa kombinasi antara probiotik dan prebiotik mampu meningkatkan populasi mikroorganisme dalam saluran pencernaan, efisiensi pakan ayam pedaging dan meningkatkan aktivitas pencernaan. Aktivitas pencernaan protein dari kontrol (T0) hingga perlakuan (T3) tidak jauh berbeda yaitu berada pada rentang 17,82 - 18,99\% (Tabel 2). Berdasarkan penelitian Hamid et al. (2014) aktivitas pencernaan yang meningkat dan berkembangnya bakteri akan mengakibatkan perubahan terhadap saluran pencernaan sehingga dapat berkembang lebih optimal. Selain itu, Chaiyasut et al. (2017) menyatakan bahwa kadar keasaman yang meningkat mengakibatkan bakteri patogen terlambat perkembangannya, serta aktivitas enzim-enzim pencernaan meningkat sehingga kecernaan pakan juga meningkat.

Namun hasil penelitian menunjukkan penambahan aditif pakan dalam ransum dengan dosis $50 \mathrm{ml} / \mathrm{kg}, 100 \mathrm{ml} / \mathrm{kg}$ dan 150 $\mathrm{ml} / \mathrm{kg}$ belum mampu meningkatkan bobot relatif usus halus sehingga hasilnya tidak berbeda dengan perlakuan tanpa aditif pakan. Hal ini sesuai dengan penelitian Awad et al. (2009) yang menyatakan bahwa penambahan probiotik dalam pakan tidak berpengaruh terhadap bobot relatif usus halus ayam pedaging. Berdasarkan penelitian Awad et al. (2006) bahwa pemendekan vili pada usus halus menyebabkan penyerapa nutrisi yang buruk, sekresi di saluran pencernaan meningkat dan aktivitas kerja menjadi rendah sehingga usus halus tidak mampu berkembang lebih optimal. Awad et al. (2009) menambahakan bahwa perkembangan usus halus yang diberi tambahan kombinasi antara probiotik dan prebiotik berupa lactobacillus $s p$. dengan sawi putih sebanyak $0,1 \%$ dalam ransum mengalami peningkatan karena perubahan histologis, hal tersebut disebabkan peningkatan tinggi villi sehingga aktivitas pencernaan dan penyerapan nutisis pada usus halus meningkat, tinggi vili yang meningkat adalah indikator bahwa fungsi vili menjadi aktif karena mengkonsumsi ransum dengan penambahan probiotik.

\section{Pengaruh Perlakuan Terhadap Bobot Relatif Seka}

Penambahan kulit singkong dan bakteri asam laktat sebagai aditif pakan dalam ransum dengan dosis $50 \mathrm{ml} / \mathrm{kg}, 100 \mathrm{ml} / \mathrm{kg}$ dan $150 \mathrm{ml} / \mathrm{kg}$ tidak berpengaruh nyata terhadap bobot relatif seka ayam pedaging dengan hasil perhitungan berkisar antara $0,42-0,51 \%$ (Tabel 2). Hasil tersebut dalam rentang normal. Berdasarkan penelitian Awad et al. (2009) bahwa penambahan kombinasi antara probiotik dan prebiotik berupa lactobacillus $s p$. dengan sawi putih sebanyak $0,1 \%$ dalam ransum tidak berpengaruh nyata yang menghasilkan bobot relatif seka sebesar 0,38 $0,42 \%$. Penelitian lain oleh Awad et al. (2006) bahwa dengan penambahan Deoxynivalenol (DON)10 mg dengan probiotik Eubacterium $s p$. dalam ransum sebanyak $2,5 \times 10^{8} \mathrm{cfu} / \mathrm{kg}$ menghasilkan bobot relatif seka yang berbeda nyata dari kontrol yaitu pada kisaran 1,02 $1,24 \%$.

Penambahan aditif pakan diharapkan mampu untuk meningkatkan aktivitas pencernaan sehingga seka ayam pedaging dapat berkembang dengan optimal. Seka memiliki peran dalam proses fermentasi serat kasar, karena pada usus halus tidak ada enzim untuk untuk mencerna serat kasar sehingga terjadi di seka dengan bantuan mikroorganisme. Kecernaan serat kasar dari kontrol (T0) hingga perlakuan (T3) yaitu berada pada rentang $23,34-42,87 \%$. Berdasarkan penelitian Sharifi et al. (2012) bahwa penyerapan nutrien pakan di usus halus yang tidak optimal dapat menyebabkan aktivitas pencernaan di seka meningkat sehingga bobot seka akan berkembang lebih optimal. Tossaporn (2013) menyatakan bahwa perkembangan seka ayam pedaging juga dapat dipengaruhi oleh banyak atau tidaknya pakan yang tidak tercerna atau terserap di usus halus.

Namun hasil penelitian menunjukkan penambahan aditif pakan dalam ransum 
dengan dosis $50 \mathrm{ml} / \mathrm{kg}, 100 \mathrm{ml} / \mathrm{kg}$ dan $150 \mathrm{ml} /$ $\mathrm{kg}$ belum mampu meningkatkan bobot relatif seka sehingga hasilknya tidak berbeda dengan perlakuan tanpa aditif pakan. Hal ini sesuai dengan penelitian Awad et al. (2009) yang menyatakan bahwa pemberian probiotik tidak berpengaruh terhadap bobot relatif seka ayam pedaging. Berdasarkan penelitian Awad et al. (2006) bahwa penambahan Deoxynivalenol (DON)10 mg dengan probiotik Eubacterium $s p$. dalam ransum memiliki pengaruh positif terhadap populasi bakteri dalam saluran pencernaan dan mampu memperbaiki kinerja pertumbuhan, suplementasi probiotik juga mampu menangkal toksisitas dalam usus ayam broiler sehingga seka mampu berkembang secara optimal. Awad et al. (2006) menyatakan bahwa peningkatan bobot organ dipengaruhi oleh meningkatnya aktivitas pencernaan, selain itu pemberian probiotik mampu menperbaiki fungsi pada seka sehingga terjadi perubahan morfologi pada seka ayam pedaging.

\section{KESIMPULAN}

Berdasarkan hasil yang diperoleh dapat disimpulkan bahwa penambahan aditif pada ransum tidak memberikan efek berbeda dengan perlakuan kontrol, ditunjukkan dari bobot relatif yang normal meliputi proventrikulus, ventrikulus, usus halus dan seka sehingga memberikan bobot badan akhir ayam pedaging yang sama.

\section{DAFTAR PUSTAKA}

Anggoro, L., H. I. Wahyuni, dan E. Widiastuti. 2019. Pengaruh pemberian kulit pisang fermentasi dengan Chrysonilia crassa dan Bacillus subtilis terhadap bobot relatif organ pencernaan ayam broiler. J. Peternakan. 11(4): 1-7.

Awad, W. A., J. Bohm., E. R. Fazeli., K. Ghareeb, and J. Zentek. 2006. Effect of addition of a probiotic microorganism to broiler diets contaminated with deoxynivalenol on performance and histological alterations of intestinal villi of broiler chickens. J. Poultry Science. 85 : 974-979.

Awad, W. A., K. Ghareeb., S. A. Raheem, and J. Bohm. 2009. Effects of dietary inclusion of probiotic and synbiotic on growth performance, organ weights, and intestinal histomorphology of broiler chickens. J. Poultry Science. 88: 49-55.

Badan Pusat Statistik (BPS). 2018. Populasi Ayam Ras Pedaging Menurut Provinsi Tahun 2018. Badan Pusat Statistik, Jakarta.

Badan Pusat Statistik (BPS). 2015. Populasi Umbi Kayu Menurut Provinsi Tahun 2015. Badan Pusat Statistik, Jakarta.

Bozkurt, M., K. Kucukyilmaz., A. U. Cath, and M. Cinar. 2009. The effect of single or combined dietary supplementation of prebiotics, organic acid and probiotics on performance and slaughter characteristics of broilers. J. Animal Science. 39(3): 197-205.

Chaiyasut, C., T. Pattananadecha., S. Sirilun., P. Suwannalert., S. Peerja, and B. S. Sivamaruthi. 2017. Synbiotic preparation with lactic acid bacteria and inulin as a functional food: in vivo evaluation of microbial activities and preneoplastic abberant crypt foci. J. Food Sci. Technol. 37(2): 328 - 336.

Hamid, I. S., B. P. S. Rahardjo, dan M. Gabriela. 2014. Potensi pemberian sinbiotik pada umur yang berbeda pada gambaran histologi ileum ayam pedaging betina. J. Vetenaria Medika. 7(2): 114-119.

Handoko, H., Nurhayati, dan Nelwida. 2013. Penggunaan tepung kulit buah nanas dalam ransum terhadap bobot relatif organ pencernaan dan usus halus ayam pedaging yang disuplementasi yoghurt. Jurnal Penelitian Universitas Jambi Seri Sains. 15(1): 53-59.

Hidayat, C. 2009. Peluang penggunaan 
kulit singkong sebagai pakan unggas. Prosiding Seminar Nasional Teknologi Peternakan dan Veteriner. Balai Penelitian Ternak, Bogor. 655- 664.

Hossain, M. M., M. Begum, and I. H. Kim. 2015. Effect of Bacillus subtilis, Clostridium butyricum and Lactobacillus acidophilus endospores on growth performance, nutrient digestibility, meat quality, relative organ weight, microbial shedding and excreta noxious gas emission in broilers. J. Veterinarni Medicina. 60(2): $77-86$.

Iskandar, S. 2004. Respon pertumbuhan dan perkembangan alat pencernaan ayam anak silangan pelung $\mathrm{x}$ kampung terhadap kandungan protein ransum. J. Ilmu Ternak dan Veteriner. 9(4): 217225.

Kementerian Pertanian. 2017. Permentan nomor 14 tentang Klasifikasi Obat Hewan. Pusat Data dan Sistem Informasi Pertanian, Jakarta.

Mahmilia, F. 2005. Perubahan nilai gizi tepung Eceng Gondok fermentasi dan pemanfaatannya sebagai ransum ayam pedaging. JITV. 10(2) 90-95.

Park, J. H. and I. H. Kim. 2014. Supplemental effect of probiotic Bacillus subtilis B2A on productivity, organ weight, intestinal Salmonella microflora, and breast meat quality of growing broiler chicks. J. Poultry Science. 93: 2054-2059.

Selviana, N. M., E. Suprijatna, dan L. D. Mahfudz. 2019. Pengaruh penambahan kulit singkong fermentasi dengan bakteri asam laktat sebagai aditif pakan terhadap produksi karkas ayam kampung super. J. Peternakan. 3(1): 77-85.
Sharifi, S. D., F. Shariatmadari, and A. Yaghobfar. 2012. Effects of inclusion of hull-less barley and enzyme supplementation of broiler diets on growth performance, nutrient digestion and dietary metabolisable energy content. J. of Central European Agriculture. 13(1): 193-207.

Siswohardjono, W. 1982. Beberapa Metode Pengukuran Energi Metabolis Bahan Makanan pada Itik. Makalah Seminar Fakultas Pascasarjana. Institut Pertanian Bogor, Bogor.

Sugiharto., Isroli., T. Yudiarti, and E. Widiastuti. 2018. The effect of supplementation of multistrain probiotic preparation in combination with vitamins and minerals to the basal diet on the growth performance, carcass traits, and physiological response of broilers. J. Veterinary. 25(11): 240-247.

Sumarsih, S., B. Sulistiyanto., C. I. Sutrisno, dan E. S. Rahayu. 2012. Peran probiotik bakteri asam laktat terhadap produktivitas unggas. J. Litbang. 10(1): 1-9.

Tamalludin, F. 2012. Ayam Broiler, 22 Hari Panen Lebih Untung. Penebar Swadaya, Jakarta.

Tossaporn, I. 2013. Histological adaptations of the gastrointestinal tract of broilers fed diets containing insoluble fiber from rice hull meal. American J. of Animal and Veterinary Sciences. 8(2): 79-88.

Ulupi, N., I. R. H. Soesanto, dan S. K. Inayah. 2015. Performa Ayam Broiler dengan Pemberian Serbuk Pinang sebagai Feed Aditive. J. Ilmu Produksi. 3(1) : 8-11. 